NATALIA BIŁOUS

Instytut Historii Ukrainy Narodowej Akademii Nauk Ukrainy

\title{
MIASTA PRYWATNE KIJOWSZCZYZNY \\ W XVI I PIERWSZEJ POEOWIE XVII W.: SPECYFIKA ROZWOJU I FUNKCJONOWANIA
}

Zarys treści: XVI w. i pierwsza połowa XVII w. to okres dynamicznego rozwoju sieci miejskiej w województwie kijowskim. Ważną cezurą w nasileniu tego procesu było zawarcie unii lubelskiej w 1569 r. W artykule omówiono dotychczasowe ustalenia dotyczące liczby miast. Według przeprowadzonych badań przed $1648 \mathrm{r}$. istniało tam 328 miast prywatnych, w tym $20 \mathrm{w}$ dobrach kościelnych. Przedstawiono również funkcje miast Kijowszczyzny oraz specyfikę ich rozwoju jako ośrodków pogranicznych.

The content outline: The $16^{\text {th }}$ century and the first half of the $17^{\text {th }}$ century was a period of dynamic growth of the urban network in Kijowskie Voivodeship. An important starting point for the intensification of the process was the 1569 Union of Lublin. The paper contains a discussion of the data concerning the number of towns collected so far. According to the research, there were 328 private towns in the region before 1648, including 20 towns situated on Church-owned estates. The paper also presents the function of the towns of Kijowszczyzna and the nature of their development as borderland towns.

Słowa kluczowe: miasta prywatne, prawo magdeburskie, przywileje, terytoria pogranicza, województwo kijowskie, XVI i XVII w.

Key words: private towns, Magdeburg law, privileges, borderlands, Kyiv Voivodeship, $16^{\text {th }}$ and $17^{\text {th }}$ century

W XVI i pierwszej połowie XVII w. sieć miejska w województwie kijowskim ulegała ciagłym przemianom. Był to bowiem burzliwy okres rozwoju starych i powstawania wielu nowych miast. Unia lubelska zawarta w 1569 r. stała się ważnym bodźcem do aktywizacji 
procesu urbanizacyjnego $\mathrm{w}$ tym regionie, przebiegającego $\mathrm{w}$ kilku etapach ${ }^{1}$. Właśnie $\mathrm{w}$ okresie pounijnym powstała największa liczba miast prywatnych.

Próby obliczenia liczby miast w województwie kijowskim podejmowali wcześniej historycy zarówno polscy, jak i ukraińscy. Według Aleksandra Jabłonowskiego w latach 30. XVII w. było 206 miast, z których 46 było królewskich, 150 zaś prywatnych (w tym 10 należało do właścicieli duchownych) ${ }^{2}$. Ukraiński historyk Iwan Krypiakiewicz uważał, że w tym regionie w latach 40 . XVII w. istniało 385 miast, z których 200 pojawiło się w pierwszej połowie XVII w. ${ }^{3}$ Olena Kompan podkreślała, że wskutek kolonizacji wschodnich terenów ziem ukraińskich w pierwszej połowie XVII stulecia powstało blisko 300 nowych miast i miasteczek, z których $80-90 \%$ było prywatnych ${ }^{4}$. Witold Bobiński obliczył łączną liczbę tych miast na $290^{5}$. Z kolei Włodzimierz Buczko podał, że na Kijowszczyźnie do połowy XVII w. funkcjonowało 285 miast, w tym 52 królewskie, 13 duchownych oraz 220 należących do szlachty i magnaterii. Dodał on też, że 104 ośrodki rządziły się prawem magdeburskim ${ }^{6}$. Zarówno podział na poszczególne typy własności, jak i liczba miast posiadających prawo niemieckie budzi wątpliwości. $\mathrm{Z}$ moich wieloletnich badań wynika, że niezwykle trudno, z powodu luk w zasobie źródłowym, zaliczyć wiele miast np. do domeny monarszej czy dóbr prywatnych. Jednakże udało się powiększyć liczbę tych ostatnich. Około 1648 r. na terenie województwa kijowskiego istniało według moich obliczeń 328 miast prywatnych (w tym $20 \mathrm{w}$ dobrach duchowieństwa). Dla 33 zachowały się teksty przywilejów nadających im

${ }^{1}$ N. Biłous, Wptyw unii lubelskiej na rozwój urbanizacji województwa kijowskiego, w: Unia lubelska z 1569 roku. Z tradycji unifikacyjnych I Rzeczypospolitej, red. T. Kempa, K. Mikulski, Toruń 2011, s. 201-208; taż, Урбанізація Київського воєводства у XV-XVII ст.: основні етапи та особливості, w: Scientia nihil est quam veritatis imago. Studia ofiarowane profesorowi Ryszardowi Szczygłowi $w$ siedemdziesięciolecie urodzin, red. A. Sochacka, P. Jusiak, Lublin 2014, s. 184-202.

2 Źródta dziejowe, t. 22: PolskaXVIwieku pod względem geograficzno-statystycznym, t. 11: Ziemie Ruskie. Ukraina (Kijów-Bracław), dz. 3, oprac. A. Jabłonowski, Warszawa 1897, s. 227-233, 241.

${ }^{3}$ I. Крип'якевич, Богдан Хлельницький, Київ 1954, s. 34.

${ }^{4}$ О. Компан, Міста України в другій половині XVII cm., w: Історик Олена Колпан. Матеріали до біографбї, орrac. Я. Компан, Київ 2007, s. 58-67, 111.

${ }^{5}$ W. Bobiński, Województwo kijowskie w czasach Zygmunta III Wazy, Warszawa 2000 .

${ }^{6}$ W. Buczko, Miasta prywatne w strukturze majatków magnackich na Kijowszczyźnie drugiej połowy XVI i pierwszej połowy XVII wieku, w: Patron i dwór. Magnateria Rzeczypospolitej $w$ XVI-XVIII w., red. E. Dubas-Urwanowicz, J. Urwanowicz, Warszawa 2006, s. 88. 
prawo magdeburskie. Kolejnych 70 zaliczono do tej grupy na podstawie wzmianek o wójcie, urzędnikach miejskich oraz księgach miejskich ${ }^{7}$. Należy wspomnieć, że badanie dziejów tych miast jest utrudnione właśnie przez brak dla tego regionu ksiag miejskich.

\section{Założenie nowych miast i słobód}

Pewną liczbę osiedli typu miejskiego, powstałych pod koniec XVI w., zbudowano na miejscu osad już istniejących, niekiedy w czasach staroruskich. Część z nich utożsamia się z dawnymi miastami znanymi z latopisów, np.: Wasylków (dawny Wasylów), Biała Cerkiew (Jurijew), Makarów (Woronin), Biłyłówka (Rastawiec), Wołodarka (Włodarów), Rużyn (Szczerbów), Antonów (Rozwołoż).

Przeważająca większość lokacji w województwie kijowskim została przeprowadzona na skutek działalności przedstawicieli rodów ksiązęcych (wśród nich wymienić można: Ostrogskich, Zasławskich, Wiśniowieckich, Koreckich, Rużyńskich, Zbaraskich, Domontów, Czartoryskich). Założycielami nowych miast byli także przedstawiciele rodzin szlacheckich (Niemiryczowie, Tyszkiewiczowie, Sapiehowie, Hojscy, Lubomirscy, Zamojscy, Koniecpolscy, Charlęscy, Firlejowie, Potoccy, Kalinowscy, Leszczyńscy, Olizary, Łozkowie, Woroniczowie, Makarewiczowie-Iwaszeńcewiczowie, Suszczańscy-Proskurowie, Tyszy-Bykowscy, Strybyle i inni) ${ }^{8}$. Przedstawiciele tych rodzin założyli nie mniej niż 227 miasteczek, czyli 70\%.

Po rewizji z 1570 r., przeprowadzonej w celu oszacowania „pustek” w województwach kijowskim, bracławskim i podolskim, król Stefan Batory, a później jego następca Zygmunt III, zamierzali przekazać niezasiedlone ziemie „zasłużonym osobom”, czyli weteranom wojennym. Jednak działania te wywołały sprzeciw sejmu, który niechętnie godził się na oddanie nieużytków w prywatne ręce. Na taki krok zdecydowano się kilka razy. W 1581 r. zasłużony wojskowy książę Kiryk Rużyński otrzymał przywilej na uroczysko Kotelnię pod Żytomierzem,

7 Wyniki tych badań przedstawiłam w odrębnym artykule: Н. Білоус, Приватні міста Київського воєводства в першій половині XVII ст.: кількість, особливості розвитку та фбункціонування, „Україна в Центрально-Східній Свропі” 15, 2015, s. 125-164, którego aneks zawiera pełny spis prywatnych miast woj. kijowskiego w latach 40. XVII w.

${ }^{8}$ H. Litwin, Naptyw szlachty polskiej na Ukraine 1569-1648, Warszawa 2000; tenże, Fakcje magnackie na Kijowszczyźnie 1569-1648, w: Władza i prestiż. Magnateria Rzeczypospolitej w XVI-XVIII w., red. J. Urwanowicz, Białystok 2003, s. 47-70. 
gdzie powstało miasto z zamkiem i rynkiem ${ }^{9}$. W 1582 r. Stefan Batory nadał przywilej pozwalający Dmitrowi Jelcowi na lokację miasteczka Puszczyn nad rzeka Irpień (na dawnym uroczysku Turbowszczyzna) i budowę w nim zamku ${ }^{10}$. W 1590 r. na sejmie starosta czerkaski Aleksandr Wiśniowiecki wywalczył potwierdzenie posiadania „nieużytków nad rzeka Suła”, gdzie z czasem powstało duże latyfundium z kilkoma miastami, którym nadano prawo magdeburskie (Piratyn, Żurawka, Pryłuka, Żołnin, Łochwica, Łubny, Romny, Choroł). W tymże roku Stanisław Żółkiewski otrzymał przywilej na miasta Horoszyn i Slepowrod, lecz stracił je na rzecz książąt Wiśniowieckich, natomiast w $1597 \mathrm{r}$. otrzymał Boryszpol z włościa.

W XVII w. rozdawnictwa królewszczyzn stały się częstsze. Prawdopodobnie dawna królewszczyzna Czarnobyl - miasto z zamkiem i włościa - przeszedł w prywatne ręce magnatów litewskich Sapiehów ${ }^{11}$. Według inwentarza majętności, sporządzonego w 1640 r., w mieście było 267 placów osiadłych, 150 włók ziemi, do włości należały zaś 23 wsie i słobody, których mieszkańcy płaciły podatki z 150 włók i odrabiali posługi. Pustych włók było 97, „osiadłych na czynszu” - $102^{12}$. Z kolei 23 II 1645 r. miasto Demidów z włością król przekazał Iwanowi Tyszkiewiczowi ${ }^{13}$.

Najwięcej nowych miast powstało więc w pierwszej połowie XVII w., gdy rozdawano ziemie szlachcie za zasługi wojskowe zasłużonym żołnierzom, uczestnikom ekspedycji moskiewskich i różnych bitew. $26 \mathrm{X}$ 1634 r. Łukasz Żółkiewski, starosta chmielnicki, kałuski i perejasławski, otrzymał przywilej na lokację osad miejskich na uroczyskach: Krasnopol, Hadiacz, Sarskie, Rusawka, Lutynka, Hruni, Glinsk i Bielsk ${ }^{14}$. 20 III 1637 r. Janowi Kłosińskiemu nadano przywilej na lokację Bohaczki na miejscu słobód nad rzeką Pseł, z prawem do organizacji dwu targów (we wtorek i sobotę) oraz czterech jarmarków

9 Rosyjskie Archiwum Państwowe Akt Dawnych w Moskwie (dalej: RAPAD), zesp. 389, op. 1, ks. 216, 217 v-219 v.

${ }_{10}$ Centralne Państwowe Historyczne Archiwum Ukrainy w Kijowie (dalej: CPHAUK), zesp. KMF-32, sygn. 97.

11 E. Rulikowski, Czarnobyl, w: Stownik geograficzny Królestwa Polskiego i innych krajów słowiańskich, t. 1, red. F. Sulimowski, B. Chlebowski, Warszawa 1880, s. 751-753.

${ }^{12}$ Archiwum Państwowe w Krakowie (dział na Wawelu), Archiwum Młynowskie Chodkiewiczów, sygn. 404.

${ }_{13}$ Biblioteka Narodowa Ukrainy im. W. Wernadskiego NANU, Instytut Rękopisów (dalej: BNU, IR), zesp. 1, sygn. 4104, nr Powt-662, Przywilej Jkmci na miasteczko Demidów z przysiołkami Iwanowi Tyszkiewiczowi.

14 AGAD, Metryka Koronna, ks. 181, k. 31-31 v. 
dorocznych ${ }^{15}$. W 1638 r. porucznik Wojciech Tuszewski i jego żona Elżbieta Proskurzanka otrzymali przywilej na miasteczko Meżyryczkę w powiecie owruckim ${ }^{16}$, a w 1644 r. ich córka Helena ustapiła prawo do niego Władysławowi Chreptowiczowi, porucznikowi choragwi Aleksandra Piaseczyńskiego, kasztelana kijowskiego ${ }^{17}$. W 1639 r. żołnierzowi Stefanu Woronowskiemu nadano „pustynię” Lebedyn ${ }^{18}$. Najbardziej charakterystyczny jest przywilej dla Fedora Woronicza, podczaszego kijowskiego, rotmistrza wojska kwarcianego, uczestnika ekspedycji moskiewskich i wołoskich, na założenie miasteczka Fedorów nad rzeka Żerew w powiecie owruckim (1640): „Thedor Woronicz, pułkownik i rotmistrz nasz odważny i dzielny, animusz swój jako prawdziwy ojczyzny syn na bitnych placach wojennych z stratą dostatków i zdrowia swego wiernie i statecznie nam i Rz[eczy]p[ospoli]tej oświadczając, abyśmy w prośbach imieniem jego na ten czas przez Panów Rad naszych do nas z strony zakładania miasteczka Fedorowa na gruncie swym dziedzicznym"19. W 1646 r. książę Jeremi Wiśniowiecki otrzymał zaś przywilej od króla Władysława IV na miasta Hadziacz i Bobryk ${ }^{20}$.

Niektóre miasteczka są notowane w źródłach jako wsie, co utrudnia określenie ich statusu prawnego. Tak np. Liplany odnotowano jako wieś i jako miasteczko powiatu owruckiego: w 1640 r. Jan Liplański występował jako właściciel tego miasteczka, a $13 \mathrm{~V} 1644 \mathrm{r}$. inny jego właściciel - Hryhorij Liplański - przekazał we władanie Jeremiemu Jelcowi wieś Liplany ${ }^{21}$. Podobnie i Domontów był odnotowany jako miasteczko i jako wieś w starostwie czerkaskim. W 1643 r. książę Jeremi Wiśniowiecki przekazał w zastaw to miasteczko żonie Floriana Potockiego za 33700 zł, a potem nagle nasłał swoje sługi i usunął nabywców $^{22}$. 11 IV 1644 r. zaś oddał w zastaw wieś Domontów i futor Korobowkę Janowi Zebrzydowskiemu za 9000 zł na 3 lata ${ }^{23}$.

W tym okresie powstało dużo nowych słobód, które często pojawiały się w sąsiedztwie istniejących miast i miasteczek. W 1636 r. Stanisław Tyszkiewicz na gruntach swojej sąsiadki księżnej Chodkiewiczowej nad

15 Tamże, k. 209 v-211.

16 Tamże, ks. 183, k. 19 v-21.

17 Tamże, ks. 189 , k. 129 v-130 v.

18 Tamże, ks. 186, k. 29 v-30.

19 Tamże, ks. 185, k. 291-292.

${ }^{20}$ BNU, IR, zesp. 1, sygn. 4104, nr 1036, Oblata przywileju Władysława IV dla księcia Michała Wiśniowieckiego na dobra Hadziacz i Bobryk, 12 VI 1646 r.

${ }^{21}$ CPHAUK, zesp. 11, op. 1, ks. 9, k. 553; BNU, IR, zesp. 1, sygn. 4104, nr Powt-1000 .

${ }^{22}$ BNU, IR, zesp. 1, sygn. 4104, nr 2736.

${ }_{23}$ Tamże, nr Powt-948, 949. 
rzeką Tnia założył słobodę nazwaną Nowy Łohojsk, która po 10 latach odnotowano jako miasteczko ${ }^{24}$. W tym też roku książę Władysław Dominik Zasławski skarżył się przed sądem grodzkim na wspomnianego Stanisława Tyszkiewicza, że osadził on blisko miasta Cudnów na uroczysku Kurne miasteczko $\mathrm{z}$ taką nazwa, poprzednio splądrowawszy dąbrowy i grunty pozywającego ${ }^{25}$. W 1646 r. rodzina Tyszy-Bykowskich osadziła nową słobodę Tyszpol, która była nazywana też miasteczkiem Wyszpol $^{26}$. Tegoż roku Fedor Jelec osadził słobodkę Jelcówkę, a Osowscy - słobodę Osówkę ${ }^{27} .12$ VI 1645 r. ihumen monasteru kijowsko-pieczerskiego oskarżył Konstantego Potockiego, właściciela miasta Narodycz, o to, że jego ojciec nieboszczyk Florian Potocki osadził na gruntach sąiedniej, należącej do monasteru wsi Kleszczów, kilka słobód ${ }^{28}$. Ale najwięcej takich osiedli założono w lewobrzeżnych majątkach książat Wiśniowieckich, dokąd masowo uciekali zbiegli chłopi, poddani szlachty z prawobrzeżnej części województwa. Do nowo założonych słobód i miasteczek uciekali również poddani z majątków szlachty z powiatów: łuckiego, owruckiego i żytomierskiego. W 1645 r. źródła notuja zbiegów ze Starego Brusiłowa, własności Butowiczów, do Baryszewki, która należała do Jakuba i Teofili Sobieskich ${ }^{29}$. W 1646 r. poddani uciekli z miasteczka Cybulowa własności Aleksandra Faszczewskiego do nowo założonego przez Stanisława Lubomirskiego miasteczka Kamionki $\mathrm{w}$ starostwie białocerkiewskim ${ }^{30}$. Z tego roku mamy też informacje o zbiegach z powiatu łuckiego: ze wsi Żwirowa do miasteczka Kodni, które należało do Krzysztofa Tyszkiewicza, oraz ze wsi Romanów do miasta Słobodyszcze Antoniego Tyszkiewicza ${ }^{31}$. Atrakcyjne pod tym względem było także starostwo czerkaskie - kraj kozacki, zwłaszcza miasto Trechtymirów. 23 VI 1645 r. właściciele wsi Dmitrowicz Fedor, Katarzyna, Anna oraz Helena Humienieccy złożyli skargę do sądu na Mikołaja Zaćwilichowskiego, komisarza wojsk Jego Królewskiej Mości, domagając się zwrotu zbiegłych do Trechtymirowa chłopów ${ }^{32}$.

Po zawarciu unii lubelskiej w regionie Naddnieprza założycielami nielicznych miejscowości typu miejskiego była szlachta napływowa.

\footnotetext{
24 Tamże, nr 4104, 954.

25 Tamże, nr 938.

${ }_{26}$ Tamże, nr 1194, 1224, 1646.

27 Tamże, nr 1646.

28 Tamże, nr 246.

29 Tamże, nr 237.

30 Tamże, nr 1760.

31 Tamże, nr 1122 i inne.

${ }_{32}$ Tamże, nr 306, 309.
} 
Wśród tego typu właścicieli można wymienić rodzinę Charlęskich, przybyszów z województwa lubelskiego, dzięki którym powstało miasteczko Byszów, a wokół niego powstała włość byszowska z kilkoma wsiami. W 1581 r. podkomorzy kijowski Szczęsny Charlęski starał się u króla o nadanie prawa magdeburskiego i statusu miejskiego tej osadzie. $\mathrm{Na}$ dawnym grodzisku zbudował on swoim kosztem obronny zamek, otoczył go wałami i prosił króla o nadanie odpowiedniego przywileju. Za wzór organizacyjny nowemu miastu miał służyć Kijów. Na czele gminy miejskiej stał wójt, powoływany przez właściciela miasta ${ }^{33}$. Ośrodek otrzymał dwa jarmarki - na św. Illi (19 lipca) i św. Mikołaja (6 grudnia). Po śmierci założyciela w 1602 r. majętność przeszła w ręce jego młodszego syna - Jerzego Charlęskiego, który przyczynił się do dalszego rozwoju Byszowa. 1 VI 1616 r. wskutek jego starań król potwierdził przywilej na prawo magdeburskie ${ }^{34}$. Po jego śmierci wdowa Anna z Mikulińskich otrzymała dożywocie na Byszowie i władała nim, gdy wyszła powtórnie za mąż za Łukasza Witowskiego, podsędka kijowskiego. Jedyny syn Jerzego, Samuel Charlęski, po ukończeniu nauk na Akademii Krakowskiej udał się w podróż za granicę, ale w Augsburgu zachorował i zmarł. W testamencie swym upraszał matkę, aby zwłoki jego zostały pogrzebane w byszowskim kościele, gdzie spoczęły już ciała babki i ojca Jerzego. Zapisał też na kościół byszowski sumę 10000 złp. Jego matka odnowiła ów kościół i następnie wprowadziła do niego oo. dominikanów, którym w 1644 r. zapisała na wieczny fundusz wsie Lisznię i Dobkowszczyznę $^{35}$. Warto dodać, że w 1711 r. Kozacy spalili kościół i zamek ${ }^{36}$.

\section{Funkcje miast oraz specyfika ich rozwoju}

Miasta późnośredniowieczne i wczesnonowożytne spełniały wiele funkcji społecznych i gospodarczych: były ośrodkami administracyjnymi, siedzibami władcy (właściciela) lub jego namiestników oraz urzędników rezydujących w grodzie. Były też ośrodkami wytwórczości i handlu oraz kultu religijnego. Powolna recepcja prawa magdeburskiego

${ }^{33}$ Wzmianka o wójcie została odnotowana w księdze grodzkiej żytomierskiej z 1640 r.; CPHAUK, zesp. 11, op. 1, ks. 9, k. 43 v.

${ }^{34}$ Obydwa przywileje zostały opublikowane: Н. Білоус, Магдебурзькі привілеї Бишева та його власники, „Краезнавство” 2014, nr 1, s. 58-63.

35 BNU, IR, zesp. 1, sygn. 4104, nr 2102, 2103. Pod tym rokiem zachowała się wzmianka, że przełożony kościoła byszowskiego Samuel Rudnicki podał manifestację przeciwko panu Adamowi Gumowskiemu o nieuszanowanie kościoła; tamże, Powt-941.

${ }^{36}$ E. Rulikowski, Byszów, w: Stownik geograficzny..., t. 1, s. 516. 
w województwie kijowskim spowodowała, że miasta pod względem administracyjno-prawnym dzieliły się na uprzywilejowane (rządzące się prawem magdeburskim) i nieuprzywilejowane (z funkcjonowaniem instytucji wójta, ale bez przywilejów prawa niemieckiego i organów samorządowych). Podobnie jak i w innych regionach Wielkiego Księstwa Litewskiego i Korony Polskiej, w tym regionie wiele miasteczek miało status osady pośredniej między miastem a wsią. Miały one też agrarny charakter, wielu bowiem mieszczan parało się tego typu zajęciami. Według Jerzego Ochmańskiego zasadniczym źródłem utrzymania ludności tych ośrodków była uprawa roli, ale pełniły one funkcje gospodarcze miasta. Organizowano w nich targi, jarmarki, znajdowały się karczmy, kramy i warsztaty rzemieślnicze ${ }^{37}$. Wiek XVI to okres, kiedy powstała znaczna liczba średnich i małych miast, co wiązało się z potrzebą państwa oraz magnaterii i szlachty, zainteresowanych w zakładaniu takich osad ${ }^{38}$. Wiele miasteczek charakteryzowało się niewysokim stanem zaludnienia i rozległością terenów miejskich z luźną zabudowa. Drewniane domki typu wiejskiego, posiadające przydomowe ogrody warzywne i sady, wypełniały przestrzeń miejska i tylko przy rynku tworzyły się zwarte szeregi budynków.

Ze względu na pograniczny status województwa kijowskiego jedną z najważniejszych funkcji miast prywatnych tego regionu była działalność obronna. Zdaniem Tomasza Opasa, „miasta pograniczne z racji swych obronnych i handlowych funkcji otoczone były w pewnych okresach większą opieką ze strony pańswa, również gdy były to miasta prywatne" ${ }^{39}$. Król, deklarujący potrzebę budowania zamków obronnych, nie miał na to środków. Z tego powodu jego udział w akcji kolonizacyjnej ograniczał się do wspierania prywatnych inicjatyw. Władzom Korony zależało przede wszystkim na wzmacnianiu systemu obronnego w lewobrzeżnej części województwa, przed agresja głównie ze strony państwa moskiewskiego. W każdym z tych miasteczek budowano zamek oraz fortyfikacje, wytyczano także rynek, tworzono warunki dla rozwoju handlu i rzemiosła, o czym zachowały się wzmianki źródłowe ${ }^{40}$.

37 J. Ochmański, W kwestii agrarnego charakteru miast Wielkiego Księstwa Litewskiego, w: Studia historica w 35-lecie pracy naukowej Henryka Eowmiańskiego, Warszawa 1958, s. 293-294; K. Pietkiewicz, Wielkie Księstwo Litewskie pod rzqdami Aleksandra Jagiellończyka. Studia nad dziejami państwa i społeczeństwa na przełomie XVi XVI w., Oświęcim 2014, s. 205.

${ }^{38}$ R. Szczygieł, Udziat magnaterii $w$ urbanizacji ziem polskich $w$ XVI wieku, „Acta Universitatis Wratislaviensis", nr 945, Historia LXVI, 1988, s. 249-250.

39 T. Opas, Miasta prywatne a Rzeczpospolita, KH, t. 78, 1971, nr 1, s. 31.

${ }^{40} \mathrm{Na}$ przykład: „Третий припозов до маетности велможного кнежати Еремияша Михала Корыбута Вишневецкого и там тот припозов в браму замковую в том 
Przy zakładaniu każdej osady miejskiej należało w pierwszym rzędzie uwzględnić możliwości i potrzebę obrony przed częstymi najazdami oddziałów tatarskich. W tej sytuacji lokację miasta zaczynano od budowy zamku. Przywileje lokacyjne nie daja możliwości prześledzenia tej tendencji. Ze względu na brak ksiąg miejskich wzmianki takie udało się odnaleźć w księgach grodzkich, gdzie odnotowano informacje o tym, że prawie w każdym (dużym czy małym) miasteczku był zbudowany zamek albo zameczek oraz umocnienia obronne. Wznoszono przeważnie drewniane lub drewniano-ziemne konstrukcje. Miasteczka otaczano więc wałem, na którym wznoszono częstokół, a także fosa. Wykorzystywano warunki przyrodnicze, sytuując zamki na wyniosłościach $^{41}$. Halina Petryszyn uważa, że słobody były także szybko i dobrze fortyfikowane. Skupione w ciagu pasów obronnych, osłaniały od strony „pola” rejony osadnicze ${ }^{42}$.

Co charakterystyczne, nowe miasta powodowały osiedlanie się wokół nich ludności wiejskiej, która mogła uniknać napadów tatarskich, chroniąc się za umocnieniami takich „zameczków”. Tatarzy zazwyczaj nie atakowali umocnionych punktów. Ich taktyka polegała na błyskawicznym napadzie i równie szybkim odwrocie. Dlatego powstanie miast sprzyjało zagęszczaniu sieci osad wiejskich, przez co wzrastały możliwości gospodarcze danej włości; tworzyły się więzi gospodarcze, społeczne i religijne. Ludność napływająca do miasteczek miała zapewnione prawa i swobody gwarantowane przez prawo miejskie.

Istotna wadą budowanych $\mathrm{z}$ drewna zameczków była ich niewielka odporność na pożary. W 1638 r. sługa Fedora Tyszy-Bykowskiego wniósł protestację do ksiag grodzkich żytomierskich o zniszczeniu majętności jego pana w Chodorkowie, gdy 15 lutego w północ „zgorzały" w nim wszystkie budynki. Zachowała się tylko jedna wieża (pewnie była murowana), gdzie przechowywano przywileje i tytuły prawne do majętności chodorkowskiej ${ }^{43}$. Tegoż roku pożar zniszczył tė̇ zamek w Korninie, gdzie również spłonęły wszystkie przywileje na majętności oraz księgi ziemskie kijowskie za 1638 r., które przed tym

месте Прылуце будучую воткнувши челяди в том замку будучой, сторожом, также мещаном на рынку стоячим оповедал"; CPHAUK, zesp. 11, op. 1, ks. 9, k. 246.

${ }^{41}$ Zob. np. I. Кондратьев, Любецьке староство (XVI - середина XVII cm.), Чернігів 2014, s. 130-134.

${ }^{42}$ H. Petryszyn, Ruch urbanistyczny doby nowożytnej na terenach Ukrainy. Typologia miast i interpretacja wzorców lokacyjnych (XVI - połowa XVII wieku), w: Procesy lokacyjne miast $w$ Europie Środkowo-Wschodniej, red. C. Buśko, M. Goliński, B. Krukiewicz, Wrocław 2006, s. 282-283.

${ }^{43}$ CPHAUK, zesp. 11, op. 1, ks. 9, k. 215. 
wydarzeniem Fedor Suszczański-Proskura, pisarz ziemski kijowski, zawiózł do tego zamku ${ }^{44}$.

Rozwój zaludnienia i zagospodarowania terenów południowych i południowo-wschodnich, jaki wówczas obserwujemy, nastapił wskutek zmniejszenia zagrożenia ze strony Tatarów oraz dzięki polityce władz sprzyjających ludziom, którzy z własnej inicjatywy osiedlali się blisko szlaków tatarskich. Praktykowany w Koronie system obronny pogranicza okazał się o wiele skuteczniejszy niż ten, który dotąd istniał w Wielkim Księstwie Litewskim. Szczególnie ważne okazało się utworzenie wojska kwarcianego, broniacego strefy południowego pogranicza. W latach 70. XVI w. powstała też struktura wojska zaporoskiego, jako dodatkowej siły zabezpieczającej rubieże kraju. Oprócz tego tworzone były wojska nadworne książąt oraz panów kijowskich, które brały na swoje barki dużą część antytatarskich działań wojennych, a na rozkaz hetmanów przyłączały się do wojska kwarcianego. Działania takie nie rozwiązały zupełnie problemu tatarskiego, znacznie jednak przyczyniły się do tego, że w drugiej ćwierci XVII w. wzrósł poziom bezpieczeństwa ${ }^{45}$.

Właściciele miast prywatnych Kijowszczyzny duże znaczenie przywiązywali do organizacji handlu i rzemiosła. We wszystkich przywilejach lokacyjnych zawarte było zezwolenie na prowadzenie targów i jarmarków. Otrzymało je w przywileju z 1616 r. miasteczko Nowy Staw Krzysztofa Makarewicza-Iwaszencewicza, które miało wzorować się na Krakowie i Lwowie: „К tomu dopuszczajem w miestie Nowom Stawie ratusz zbudowati i kramy, wagu, postrygalniu, jatki wsiakije, łazniu pospolituju i sztokolwiek do poriadku obychodow i pożytkowi miestskomu należyt mieti. I remesła cechowyje poriadkom inszych takowych miest sporiadywszy wo wsiem sprawowati. Także mieti dozwolili jesmo i tym listom naszym dozwolajem Krysztofowi Makarewiczowi w tom miesteczku Nowom Stawu ustawiti jarmarki dwa w kożdyj god”46. Jerzy Lasota, właściciel Sarnopola, w 1615 r. otrzymał

44 Tamże, k. 139.

${ }_{45}$ N. Jakowenko, Historia Ukrainy do 1795 roku, tłum. A. Babiak-Owad, K. Kotyńska, Warszawa 2011, s. 246.

${ }^{46}$ RAPAD, zesp. 389, ks. 207, k. 52 v-53: „К тому допущаєм в месте Новом Ставе ратушъ збудовати и крамы, вагу, постригалню, ятки всякие, лазню посполитую и што-колвек до порядку обыходов и пожиткови местскому належит мети. И ремесла цеховые порядком инъших таковых мест спорядивши во всем справовати. Также мети дозволили есмо и тым листом нашим дозволяємъ Крыштофови Макаровичови в том местечку Новом Ставу уставити ярмарки два в кождый год” (5 VII 1616 r.). 
przywilej na organizację jednego jarmarku i dwu targów w tym mieście: „A tak my, hospodar, baczaczy met prozbu jego w tom słusznuju w tom mesteczku jego Sarnopolu jarmarok odin uroczystyj na swiatki swiata rymskoho i torgi dwa na kożdyj tyżden: odyn w den ponedełkowyj, a drugi w den piatnicznyj derżati i torgowoje wybirati pozwolili jesmo, i sym listom naszym pozwolajem wiecznymi czasy. Dajuczy wolnost jako mieszczanom sarnopolskim, tak i ludem postoronnim i czużozemskim zagranicznym na torgi pomenenyje i jarmarok uroczystyj do toho mesteczka Sarnopola prijeżdżaty i torgy czynyty, szynkowaty piwom, medom, horiłkoju, winom i bragoju, koni, inoje wsiakoje bydło prodawati, kupowaty towary kosmatyje, sukonnyje i innyje wsiakyje za towary meniaty i wsiakije handli prowadyty" ${ }^{47}$. Najczęściej pozwalano na organizację dwu jarmarków rocznie. Prawo do organizowania doroczne trzech jarmarków otrzymały tylko trzy miasta: biskupi Fastow ${ }^{48}$ i dwa szlacheckie - Fedorów ${ }^{49}$ i Dobromir ${ }^{50}$, cztery zaś nadano zakładanemu przez Jana Kłosińskiego miastu Bohaczka nad rzeką Pseł: „Także iarmarki w każdy rok cztery: pierwszy przed Wstapieniem Bożym tygodniem, drugi przed Wniebowzięciem Naswiętszej Panny Mariej tygodniem, trzeci przed Ś. Mikołajem jesiennym, także tydniem, ostatni na Ś. Macieja wedle starego kalendarza. Które to jarmarki i targi pomienione obywatele w miastach i miasteczkach naszych królewskich, duchownych i szlacheckich na jarmarkach i targach każą obwołać i to wszystkim do wiadomości przywieść. A na te targi i jarmarki czasów zwysz naznaczonych wolno będzie wszystkim, jakimi-kolwiek conditiej ludziom, kupcom, rzemieśnikom (wyjąwszy tych, którzy według prawa pospolitego do takich zjazdów przypuszczeni być nie maja), przyieżdżać, handle, kupiectwa rozmaite odprawować w tym że miasteczku przez cały tydzień i tak konie jako i woły, i inne dobytki, i bydła małe i wielkie kupować, przedawać, zamieniać,

47 Tamże, k. 16 v: „А так мы, господар, бачачи мет прозбу его в том слушную в том то местечку его Сарнополю ярмарок один урочистый на святки свята римского и торги два на кождый тыйден: один в ден понеделковый, а другий в ден пятничный держати и торговое выбирати позволили есмо, и сим листом нашим позволяем вечными часы. Даючи волност яко мещаном сарнополским, так и людем посторонним и чужоземским заграничным на торги помененые и ярмарок урочистый до того местечка вперед реченого Сарнополя приежджати и торги чинити, шинковати пивом, медом, горилкою, вином и брагою, кони, иное всякое быдло, продавати, куповати товары косматые, суконные и иные всякие за товары меняти и всякие гандли провадити”.

${ }^{48}$ AGAD, Metryka Koronna, ks. 147, k. 50.

49 Tamże, ks. 185, k. 291 v.

50 Tamże, k. 410 v. 
frymarczyć każdemu według upodobania i lepszego pożytku swego. Których to koni i bydła rozmaitego przedawanie ma poprzedzać jarmarki naznaczone dniem albo dwiema. A żeby się tym bespiecznej na przerzeczone jarmarki do miasteczka Bohaczki ludzie zieżdżali, chcemy tego, aby wszystkim wolna i bespieczna, tak przyieżdżajacym, jako i odieżdżającym według prawa pospolitego była droga. Do tego wolnemi obywatelów przerzeczonego miasteczka czyniemy od ceł i myth jakim-kołwiek imieniem nazwanych, tak wodnych, jako i lacdowych w państwach naszych do lath dziesiąci, chcąc aby ta wolność tak tym obywatelom miasteczka Bohaczki, którzy końmi, wołami i innym bydłem handluja, jako tesz i tym, którzy innemi rozmaitemi kupczą towarami służyła"

Warunki sprzyjające ożywieniu ruchu lokacyjnego stwarzała także polityka władz, która wyrażała się w obdarzaniu pogranicznych miast, w szczególności nowych, zwolnieniami od podatków i wolnościami celnymi, a także dłuższymi okresami tzw. wolnizny, czyli zwolnieniem od czynszów, podatków i powinności na okres od kilku do 30 lat. Jako „ludzie ukrainni” ich mieszkańcy na terenach całej Rzeczypospolitej zwolnieni byli też z opłat targowych i jarmarcznych.

Małe miasta pełniły specyficzne funkcje handlowe: odgrywały ważna rolę pośredników między wielkim handlem prowadzonym w dużych miastach a indywidualnymi konsumentami czy wytwórcami. Miasta prywatne uczestniczyły też $\mathrm{w}$ skupie krajowych surowców i towarów dla celów wielkiego handlu ${ }^{52}$. Świadczy o tym kalendarz jarmarków, układany tak, by ich terminy o kilka dni wyprzedzały lub następowały po jarmarkach w większych miastach, co wynika $\mathrm{z}$ omawianych przywilejów.

Informacje o rynku lub placu rynkowym poza przywilejami czerpiemy zwykle z oświadczeń woźnych, odnotowanych w księgach grodzkich. Na przykład w 1640 r. „woźny Jan Szczerbicki [...] odniósł pozew do miasta Kotelni i ten pozew u wrota bramy zamku tamecznego wetknął i sługom na ten czas w zamku będących o położeniu jego opowiadał i publikował, i mieszczanom z wójtem na rynku stojącym jawnie ogłosił" "53. Z tego oświadczenia dowiadujemy się, że w miasteczku był zamek oraz rynek, urzędował też wójt. Takich wzmianek jest więcej. W ten sposób udało się ustalić posiadanie przez osadę Kowszowata

${ }^{51}$ Tamże, ks. 182 , k. 210 v-211.

${ }^{52}$ A. Wyrobisz, Mate miasta $w$ Polsce $w$ XVI $i$ XVII $w$., w: Miasta doby feudalnej $w$ Europie Środkowo-Wschodniej. Przemiany społeczne a układy przestrzenne, red. A. Gieysztor, T. Rosłanowski, Warszawa 1976, s. 182-183.

${ }^{53}$ CPHAUK, zesp. 11, op. 1, ks. 9, k. 246 v. 
prawa magdeburskiego, gdyż w 1640 r. w tejże księdze grodzkiej odnotowane sa informacje o tamtejszych wójcie, burmistrzach i rajcach ${ }^{54}$.

Przywileje prawa magdeburskiego nadawane były zarówno już istniejącym miastom, jak i nowo zakładanym. Inicjatorami nadań byli ich właściciele - osoby świeckie lub duchowne. Za wzór organizacyjny nowych gmin służyły miasta królewskie. W przywilejach zaznaczano, że prawo magdeburskie było nadawane według wzoru innych głównych miast - Krakowa, Lwowa albo Kijowa. W przywileju dla Nowego Rużynowa podano, że porządek zgodnie z prawem magdeburskim ma zostać zachowany podobnie jak w innych miastach głównych - Krakowie i Lwowie ${ }^{55}$, w przywileju zaś dla Didowa, należącego do metropolity kijowskiego, zalecano wzorować się na Kijowie ${ }^{56}$.

W przywilejach wspominano o powoływaniu organów samorządowych: „przed urzędem miejskim my te moc i władzę zupełną wójtowi, burmistrzowi, radzie i całemu pawołockiemu urzędowi miejskiemu dajemy, we wszystkich sprawach ważnych i sądowych, które zgodnie z prawem magdeburskim do nich należa, sądzić, skazywać i postępować według innych artykułów tego prawa" (Pawołocz, 1589) ${ }^{57}$. Zapisano też informację o prawie właściciela do wyboru urzędników miejskich oraz podkreślano ich podległość dziedzicowi. W przywileju dla Sołtanowa z 1590 r. sformułowano to następująco: „wspomnianemu miastu prawo magdeburskie i wolność miejską nadajemy, że przez wójta, burmistrzów, rajców i innych urzędników miejskich od Iwana Sołtana ustanowionych cały porządek będą sprawować i utrzymywać" ${ }^{58}$. Najwyższą instancja sądową i apelacyjną dla mieszkańców miast prywatnych byli ich właściciele ${ }^{59}$.

Mieszkańcy miast prywatnych otrzymywali zezwolenie na wznoszenie budowli o różnym przeznaczeniu, np. kramów, wag, łaźni i innych. Nie we wszystkich przywilejach znajduja się zezwolenia na wzniesienie ratusza, ale $\mathrm{w}$ większości miast one istniały. Zachowały się tė̇ nieliczne informacje o nadaniu miastom prywatnym pieczęci oraz herbu. Jako przykład można wymienić miasteczko Moszny w starostwie czerkaskim, któremu na prośbę jego właściciela, księcia Aleksandra Wiśniowieckiego, Zygmunt III Waza nadał 9 II 1592 r. przywilej zezwalający na używanie herbu Oszczep oraz pieczęci miejskiej, „którą

\footnotetext{
${ }^{54}$ Tamże, k. 328 v.

${ }_{55}$ RAPAD, zesp. 389, op. 1, ks. 199, k. 119.

56 Tamże, ks. 201, k. 91 v.

57 Tamże, ks. 197, k. 10.

58 Tamże, ks. 199, k. 86 v.

59 Tamże, ks. 197, k. 10.
} 
tą pieczęcią w tym mieście Moszny urząd miejski wszystkie sprawy według prawa magdeburskiego będzie pieczętował i odprawiał, i będzie jej używał wiecznie"60.

Jednak większość miasteczek w województwie kijowskim były to ośrodki nieuprzywilejowane prawem magdeburskim. Korzystały więc z uproszczonych form samorządu. Najczęściej w źródłach odnotowane sa wzmianki tylko o wójcie i mieszczanach. Często od osiedli typu wiejskiego różniły ich prawa na odbywanie targów i jarmarków. Szerszej autonomii takie ośrodki nie posiadały. Jak trafnie zauważyła Urszula Augustyniak, władza królewska za czasów Zygmunta III w polityce miejskiej realizowała prymat władzy centralnej nad samorządem miejskim i nie była zainteresowana wzmacnianiem miejskiej autonomii ${ }^{61}$. W związku $\mathrm{z}$ tym miastom nadawano przeważnie przywileje o charakterze ekonomicznym, ulgi sprzyjające rozwojowi handlu i rzemiosła. W 1616 r. Stanisław Charlęski otrzymał od króla przywilej na jarmarki i targi dla swego miasteczka Chabne, stanowiącego centrum włości z zamkiem ${ }^{62}$. W 1643 r. Michałowi Jaślikowskiemu nadano przywilej dla miasteczka Tulcza, pozwalający na prowadzenie trzech jarmarków dorocznych ${ }^{63}$.

Podobnie jak w niektórych pogranicznych miastach królewskich omawianego regionu, przywileje nadawane miastom prywatnym zawierały wiele sformułowań przewidujących dla ludności miejskiej ograniczenia o charakterze społeczno-prawnym. Mieszkańcom zabraniano wychodzenia „na Pole”, przyjmowania do społeczności miejskiej osób będących w konflikcie z prawem (tzw. ludzi luźnych), zbiegów, ludzi „swawolnych” oraz Kozaków. Do tych ograniczeń należy również dodać powinności i świadczenia na rzecz właścicieli, które składały się z czynszu pieniężnego, danin w naturze, różnych posług (robocizny na polach i łąkach, usługi transportowe i komunikacyjne, naprawa grobli, reparacji dróg itd.).

$* * *$

Wydaje się, że na koniec możemy zasygnalizować pewne osobliwości w rozwoju miast prywatnych województwa kijowskiego, w których królewskie przywileje i uniwersały, stanowiące podstawę prawną życia

${ }_{60}$ Архив Юго-Западной России, издаваельй Вреленною колиссиею для разбора древних актов, учрежденной при Киевскол, Подольскол и Вольнском генерал-губернаторе, cz. 8, t. 5, Киев 1907, s. 260.

${ }^{61}$ U. Augustyniak, Informacja i propaganda w Polsce za Zygmunta III, Warszawa 1981, s. 209.

${ }^{62}$ RAPAD, zesp. 389 , op. 1, ks. 207, k. 51 v-52.

${ }^{63}$ AGAD, Metryka Koronna, ks. 186, k. 365. 
miejskiego w Rzeczypospolitej, nie zawsze były przestrzegane przez mieszkańców pogranicza. Ważną rolę dla ich funkcjonowania odgrywały uwarunkowania geograficzne, a zwłaszcza sasiedztwo ze stepem i Dzikimi Polami oraz - z drugiej strony - z państwem moskiewskim. Życie w warunkach stałego zagrożenia najazdem lub napadem kształtowało sposób myślenia i postępowania oraz rytm codzienności tychże mieszczan.

O ile do unii lubelskiej z 1569 r. proces urbanizacji Kijowszczyzny według modelu prawa niemieckiego przebiegał powoli, o tyle po tym wydarzeniu nastapiło szybkie ożywienie ruchu lokacyjnego, spowodowane przede wszystkim aktywnością gospodarcza miejscowej elity władzy - książąt i szlachty. To właśnie oni budowali zameczki oraz zasiedlali nowe miejscowości. Ponad 200 miast, które powstały w województwie kijowskim w końcu XVI oraz w pierwszej połowie XVII w., to liczba imponująca, świadcząca o udanym przebiegu procesu urbanizacyjnego. I chociaż w przeważającej liczbie wielkość tych miasteczek nie przekraczała stu posesji, spełniały one funkcje ośrodków, wokół których koncentrowało się życie gospodarcze i społeczne. Należy przyjąć, że około 1/3 z tych osiedli korzystała z prawa magdeburskiego. Funkcjonujące $\mathrm{w}$ pozostałych uproszczone formy samorządu sprzyjały aktywności mieszkańców miast w dziedzinie handlu oraz ożywianiu rzemiosła.

Treść prawie wszystkich zachowanych przywilejów lokacyjnych oddaje pograniczna specyfikę ośrodków miejskich z tego regionu. Miasta prywatne pełniły wielorakie funkcje obronne: 1) jako punkty strategiczne na wypadek agresji ze strony państwa moskiewskiego i napadów Tatarów; 2) jako miejsca schronienia w razie buntu poddanych oraz rebelii kozackich; 3) jako miejsca przechowywania skarbów i majątku ruchomego. Pełniły również funkcje gospodarcze: jako centra dóbr, ośrodki rzemieślniczo-handlowe i targowe, a także religijne i kulturalne. Wyczerpujące ukazanie ich roli w funkcjonowaniu tego regionu Rzeczypospolitej wymaga dalszych badań.

\section{Bibliografia}

Biłous N., Wptyw unii lubelskiej na rozwój urbanizacji województwa kijowskiego, w: Unia lubelska z 1569 roku. Z tradycji unifikacyjnych I Rzeczypospolitej, red. T. Kempa, K. Mikulski, Torun 2011, s. 201-208.

Biłous N., Урбанізаціл Київського воєводства у XV-XVII ст.: основні етапи та особливості, w: Scientia nihil est quam veritatis imago. Studia ofiarowane profesorowi Ryszardowi Szczygłowi w siedemdziesięciolecie urodzin, red. A. Sochacka, P. Jusiak, Lublin 2014, s. 184-202. 
Bobiński W., Województwo kijowskie w czasach Zygmunta III Wazy, Warszawa 2000.

Buczko W., Miasta prywatne w strukturze majatków magnackich na Kijowszczyźnie drugiej połowy XVI i pierwszej połowy XVII wieku, w: Patron $i$ dwór. Magnateria Rzeczypospolitej $w$ XVI-XVIII w., red. E. Dubas-Urwanowicz, J. Urwanowicz, Warszawa, 2006, s. 87-97.

Litwin H., Fakcje magnackie na Kijowszczyźnie 1569-1648, w: Wtadza i prestiz. Magnateria Rzeczypospolitej $w$ XVI-XVIII w., red. J. Urwanowicz, Białystok 2003, s. 47-70.

Litwin H., Naptyw szlachty polskiej na Ukraine 1569-1648, Warszawa 2000. Opas T., Miasta prywatne a Rzeczpospolita, KH, t. 78, 1971, nr 1, s. 28-47.

Petryszyn H., Ruch urbanistyczny doby nowożtnej na terenach Ukrainy. Typologia miast i interpretacja wzorców lokacyjnych (XVI - połowa XVII wieku), w: Procesy lokacyjne miast $w$ Europie Środkowo-Wschodniej, red. C. Buśko, M. Goliński, B. Krukiewicz, Wrocław 2006, s. 279-315.

Szczygieł R., Udział magnaterii $w$ urbanizacji ziem polskich $w$ XVI wieku, „Acta Universitatis Wratislaviensis”, nr 945, Historia LXVI, 1988, s. 249 $-256$.

Wyrobisz A., Mate miasta $w$ Polsce $w$ XVI $i$ XVII w., w: Miasta doby feudalnej $w$ Europie Środkowo-Wschodniej. Przemiany społeczne a uktady przestrzenne, red. A. Gieysztor, T. Rosłanowski, Warszawa 1976, s. 177-187.

Natalia Biłous

Private towns of the Kyiv Voivodeship in the $16^{\text {th }}-$ first half of the $17^{\text {th }}$ century. Particularities of development and functioning (Summary)

The article marks to analyse the typology, functions, quantitative characteristics and particularities of the development of private towns of the Kyiv Voivodeship in the 16th and first half of the $17^{\text {th }}$ century. The towns are provisionally subdivided into the ones with privileges that were granted the Magdeburg rights (about a third of all towns), and the unprivileged, constituting the majority. The reception of Magdeburg law in the Kyiv region was a long process. It started in 1498 when the Grand Duke of Lithuania Alexander Jagiellon used this law to charter the city of Kyiv, and lasted until the End $17^{\text {th }}$ century. The Union of Lublin (1569) became an important incentive to activate urbanization processes in the region.

Around the mid- $17^{\text {th }}$ century there were 328 private towns in the Kyiv Voivodship, of which almost a third had been established under Magdeburg Law. That implies that the region was highly urbanized. The distribution of Magdeburg Law had a positive impact on the life of the local people and gave a strong boost to the regions' economy. 
A significant portion of the surviving city privileges attest to the specificity of the region as the country's borderland. Private towns served various defensive functions: 1) they were to be strategic strongholds in case of Muscovite or Tatar aggression; 2) they offered shelter to refugees from surrounding lands during enemy attacks; 3 ) they were to be their owners' strongholds in case of Cossack or other subjects' rebellion; 4) they served as treasury for the treasures and assets of their owners. They also served important economic functions as centers of urban life, trade and artisanship, as well as cultural and religious life.

Natalia Biłous - dr, starszy pracownik naukowy w Instytucie Historii Ukrainy Narodowej Akademii Nauk Ukrainy. Specjalizuje się w badaniach nad społeczeństwem wczesnonowożytnym miast Wołynia i Naddnieprza. Autorka m.in. monografii i edycji zbiorów dokumentów: Київ наприкінці $X V-$ в першій половині XVII cm. Міська влада і самоврядування, Київ 2008; Тестаменти киян середини XVI - першої половини XVII ст., Київ 2011; Привілеї Києва кіния XV - середини XVII cm. Дослідження. Тексти, Київ 2013 oraz kilkudziesięciu artykułów i recenzji (zob. https://nas.academia.edu/NataliaBilous). E-mail: bilnat2009@gmail.com. 